\title{
Covid-19 Crisis Communication Management in Morocco: Investigating Male and Female Publics' Perceptions and Assessments of Moroccan Public Authorities' Crisis Response Strategies
}

\section{Hanane Aboulghazi}

Ibn Tofail University, School of Arts and Humanities

$\begin{array}{llll}\text { Received: 01. 11.2021 } & \text { • Accepted: 17.12.2021 } & \bullet & \text { Published: 19.12.2021 }\end{array}$

\begin{abstract}
The present research paper examines how Moroccan political public authorities' communication strategies influence Moroccan male and female publics' feedback, and the perception of government's crisis response strategies in light of a new atmosphere, a new condition at the pandemic time of the coronavirus Covid-19. The data is collected from 132 Moroccan internet users via online survey. It was conducted between May and June, 2020, after the declaration of the state of emergency, the present study gathered concrete information and viewpoints regarding Moroccan male and female internet users' feedback about political leaders' communication strategies, trust in different sources and media channels, and perception of the Moroccan political leaders' crisis communication management. The findings of the study have revealed that younger male and female publics, who got news from social media, had negative views of authority messages, and expressed more negative opinions of the government's crisis response and communication strategies as weeks went by. Therefore, trust in public authorities' decreased as the crisis evolves. Other age group, 60 years or older of the respondents get information about the crisis from institutional political sources and mainstream news media, which have been more aligned with authorities' information at the start of the health crisis. In addition, women have used multiple media platforms, but they have less direct access to information than do men. While some progress has been made in women's political use of information and news consumption during the outbreak on social media, on the overall, the participation of women in both feedback and news consumption is still very limited in Morocco.
\end{abstract}

Keywords: Covid-19, crisis communication management, social media, communication strategies

\section{INTRODUCTION}

Clear, concise and consistent communication is what political leaders, parties and government require at times of crisis. Therefore, communication in crisis situations is significant, and it is used to manage the publics' opinion; therefore, reduce the damage of the outbreak. During Covid-19 pandemic, it is important to identify a crisis before it takes place, and this is one of the main strategies of effective crisis management (Langford, 2009). In this recent pandemic of Coronavirus, effective communication with citizens is vital so that that they are aware of the risks of COVID-19 and its negative impact on different sectors, including, social, economic, political, and health sectors. Therefore, limit the spread of the virus.

However, the management of communication during Covid-19 pandemic has been widely criticized and questioned by Moroccan male and female political activists, Facebook users, and journalists. In 
fact, Moroccan political leaders were criticized based on the communication mistakes that they have made to react to and mange COVID-19 pandemic situation, and they include, the lack of authentic, valid and sufficient information about the new virus political leaders lack empathy and clear communication with the publics, the delay in offering information, the slow access to the internet, unplanned and illogical decisions making which affects Moroccan publics, and which cause anger and dissatisfactions of citizens and the government's decision making. During Covid-19 crisis situation, internet users immensely consume information, especially news concerned with the evolution of the outbreak (Edelman, 2020, WHO, 2020).

\section{LITERATURE REVIEW}

Recently, crisis communication and crisis management have been among hot issues discussed in different disciplines and sections, in politics, economics, business, and at the social, political, economic, and cultural level. "Crisis communication involves the sending and receiving of messages to prevent or lesson the negative outcomes of a crisis" (coombs, 1995, p.4). Seger, Sellnow, and Ulmer (1998) have stated the major objectives of crisis communication managers, and which include image management of blame and responsibility, providing specific information to stakeholders, generate support and assistance,

The main objectives of crisis communication management is to stop the danger, decrease risks and exercise control over its results (Figus, 2020). Informing the publics about crises needs practitioners and professionals to act proactively, react and talk to the media, and predicts the process of the events that can happen (Figus, 2020). Therefore, establishing solid channels with different publics and stakeholders, and addressing citizens, who are most affected by the pandemic, to build and maintain a prioritized and positive communication with them. These are vital techniques and strategies to deal with crisis situations and manage them effectively.

However, media platforms differ in terms of disseminating information to the publics, creating political interest, generating knowledge, and participating in civic life. Recently, with the introduction and excessive use of new communication technologies, media platforms have gone through several changes and transformations (Casero-Ripollés, 2018). Therefore, the introduction of new and complex communication technologies, particularly social media platforms makes everyone an author and content generator; internet users can share information. As a result, being informed has become a difficult function in a saturated news ecosystem. In fact, disinformation is omnipresent, and the citizens have lost trust in media (Bennett $\&$ Steven, 2018), what makes it very difficult for the publics to get trustworthy information and news about socio-political and health issues is polarization of politics, fragmentation, quick generation and share of content and information on social networking sites information, and the configuration of a high-choice media environment (VanAelst et al., 2017).

To face Covid-10 outbreak, trustworthy information that are spread by the media has become a vital tool in this health crisis situation. Therefore, one of the main tasks of media is to raise awareness and consciousness of the publics about the danger that is most of the time invisible or remote to the publics (Roslyng \& Eskjær, 2017). Emerging research studies have showen the different motivations of the publics to seek information about Covid-19 pandemic. (Austin et al., 2012; Lu; Jin, 2020), stressing the needs for trustworthy information, getting to know about the complexity of a crisis, receiving timely and unfiltered information, building relationships with others and building emotional support during the pandemic (Fraustino; Liu; Jin, 2017), and providing authentic communication (Procopio \& Procopio, 2007; Tai \& Sun, 2007). 
During crisis situations, the use of social media increases, (Fraustino et al., 2017), and internet users share whatever information they receive from social networking sites with their friends and relatives. This tendency has recently increased and continued to grow exponentially (Reuter \& Kaufhold, 2018; Thompson et al., 2017).

\section{METHODOLOGY}

Due to the national lockdown during Coronavirus pandemic, an online questionnaire have been conducted for almost a month, from May $20^{\text {th }}$ to June $20^{\text {th }}$. The present research paper has used quantitative research design, particularly questionnaires to answer the research questions. Invitations have been delivered based on a "snow-ball sample" technique (Creswell, 2009) to explain the objective of the questionnaires. A link has been used to send the questionnaires through WhatsApp, Facebook, Instagram, and LinkedIn. This online invitation has helped the research participants to disseminate the questionnaire to their contacts; therefore, saves time, energy, and money. The dissemination of the online questionnaire among the participants was based on criteria of interest and motivation for the research, so that no compensation was offered for participating in the research.

To answer the present paper's research questions, a descriptive survey method has been determined as the research tool to collect data. The descriptive online survey method was used to collate data for the study, as it is the most effective way to not only save time and money, but also to collect information without travelling across regions of Morocco. During this period of collecting data, there has been a health crisis event; therefore, Morocco has declared the state of emergency. Also online survey method shows the true dynamics of the study as the respondents are assured of their confidentiality, thus encouraging them to share accurate and true responses to the questionnaire.

This research paper revolves around four research questions based on a review of previous studies. What are the differences between Moroccan male and female in terms of the use of media platforms during the Covid-19 outbreak? How do Moroccan publics assess the political leaders' communication management? What messages sent by the government did the publics retain before the declaration of the State of Alarm? In which sources of information has the population shown the greatest confidence? How much accurate information have Moroccan publics had about Covid-19? For the sample of the present research paper to be representative, it uses a total of 200 participants. The online questionnaire was sent via social networking sites randomly to internet users in Morocco, of which 145 duly filled questionnaires were received back. Only 132 questionnaires have been completed and received by the targeted population as a final sample for analysis. Among those internet users who participated in the survey, 12 male and female political activists and bloggers in the online environment were personally interviewed via "zoom" video calling to gather more substantial information. In the sample, $71.1 \%$ are women, and $61 \%$ men. Different age groups have been included in the sample, with $49 \%$ under 30 years old. As far as their education is concerned, $68.7 \%$ of this age group is undergraduates and $48.3 \%$ are graduates.

\section{FINDINGS}

The present research paper was conducted in May and June 2020 in Morocco during Covid-19 has confirmed the essential functions and tasks of both traditional mass media and modern social media during crises. The first research question of the present research study explored the use of different media platforms during the first four weeks of the lockdown. As shown in Table 1, the findings have showed that both male and female internet users have immensely consumed media and have vastly sought information during Coronavirus pandemic and state of emergency. Television (89\%) has been 
categorized as the main source for getting news and information for Moroccans during the Corona pandemic crisis. Social media platforms including Facebook (75\%), WhatsApp (72\%), Instagram (38\%), were also among the most frequent information channels, along with other sources of information, including online newspapers (69\%), Radio (65\%), YouTube (40\%), Webs/Blogs of public institutions (36\%), twitter (33\%). Print newspapers (10\%) and Magazines (8\%) were, however, the least used information sources.

In addition to these research findings, Moroccan internet users' reliance on social media has increased during Covid-19 crisis. These information-seeking trends have revealed discrepancies and differences related to the gender of the participants and their level of education on the online survey. Men with different academic levels had a higher use of media platforms than women in general as they seek to get information about Corona pandemic. Moroccan young male and female participants and internet users under the age of 29 resort to social networking sites, such as Facebook (75\%) and WhatsApp (72\%),blogs (36\%), and Twitter (33\%) to get information and updates more than the rest of the age groups.

Unlike the Majority of young respondents who accessed internet on their mobile or smart phones to get information about the pandemic, other age group, 60 years or older of the respondents spent less than an hour on social media per day, while they have resorted to television during this challenging crisis situation, as portrayed in Fig. 2. In fact, 60 years or older group of the respondents reported a highly significant use of television (96\%) for news updates and information about the Covid-19 crisis in Morocco, while only $4.25 \%$ claimed they did not use it for the same reason. Thus, this category of people has rarely used social media platforms as a source of information. Besides, the educated people or those with higher levels of education usually read the print press.

The findings of the present research study have showed that $56 \%$ of women resort to Television 64.3\% and WhatsApp 70\% as the main source of information during health crisis situation. There has been some progress in the news consumption and political use of information on social media platforms during Covid-19 pandemic. However, in Morocco, women are not given the opportunity to participate in both feedback and consumption. Therefore, This Covid-19 pandemic enhances the old and traditional role of Moroccan women and perpetuates their state of having no voice and no tools to participate in decision makings and influence policies.

Table 1. The main source of information and news during the outbreak of Coronavirus

\begin{tabular}{lc}
\hline Main source of information & Percentage \\
\hline Television & $89 \%$ \\
Facebook & $75 \%$ \\
WhatsApp & $72 \%$ \\
Online newspapers & $69 \%$ \\
Radio & $65 \%$ \\
YouTube & $40 \%$ \\
Instagram & $38 \%$ \\
Webs/Blogs & $36 \% \%$ \\
Twitter & $33 \%$ \\
Print newspapers & $10 \%$ \\
Magazines & $8 \%$ \\
\hline
\end{tabular}


Table 2. Information source during the Covid-19 health crisis by age

\begin{tabular}{|c|c|c|c|c|c|c|}
\hline \multirow{2}{*}{$\begin{array}{l}\text { Information } \\
\text { Source }\end{array}$} & Age & & Age & Age & Age & Age \\
\hline & $\begin{array}{l}29 \\
\text { younger }\end{array}$ & or & $30-39$ years & $40-49$ years & $50-59$ years & 60 or older \\
\hline Television & $68.5 \%$ & & $75.0 \%$ & $81.4 \%$ & $88.2 \%$ & $94 \%$ \\
\hline WhatsApp & $88.5 \%$ & & $80.1 \%$ & $73.1 \%$ & $72.1 \%$ & $60 \%$ \\
\hline Facebook & $87.7 \%$ & & $71.5 \%$ & $77.4 \%$ & $60.3 \%$ & $50 \%$ \\
\hline Blogs & $48.0 \%$ & & $44.5 \%$ & $37.2 \%$ & $37.9 \%$ & $10 \%$ \\
\hline Twitter & $69.8 \%$ & & $44.6 \%$ & $16.1 \%$ & $12.4 \%$ & $11 \%$ \\
\hline
\end{tabular}

\subsection{The Management of communication in crisis situation and media use}

The present research study has adopted and adapted some interesting statements regarding favorable and unfavorable assessments of Government's communication management on Covid-19, and which includes, "communication has always been clear and sufficient"; "has been scheduled at the appropriate times"; and "has been the most reliable information", "has not revealed the whole truth", "has confused the population", "has generated social alarm", (Moreno, et al., 2020).

Based on gender analysis of the findings, the majority of Moroccan females think that the whole truth and clear information has not revealed by the Moroccan government $(66 \%)$, and that political leaders have created social alarm during the pandemic (51.8\%). Regarding differences by age, $62.5 \%$ of the young people state that the government has created social alarm. However (33.8\%) of the intermediate age groups advocate this statement.

In Morocco, there has been an increase in the publics who followed news about Coronavirus in March 2020, compared to the tracking of political news data from the previous fortnight. Thus, 57\% of Moroccan publics followed the news about Covid-19 "very closely" and 35\% "fairly closely". In total, $92 \%$ of citizens actively consumed news about the virus, compared to $8 \%$ who consumed news sporadically.

Among the respondents who assessed the government's communication management during the Covid-19 crisis in Morocco are Moroccan female and male political activists and internet users who use social media excessively. They state that the strategies and techniques of communication that have been used by political leaders during the pandemic has generated social alarm and confused the publics. These are Facebook users and practitioners who visited social media Movements frequently. Unlike social media users who have showed unfavorable assessments of the political leaders' communication or what they refer to as the communication of "the Moroccan government" during Covid-19 pandemic, official print newspapers consumption have showed that the communication strategies of those in position of power have always been clear and sufficient (53\%), has been scheduled at the appropriate time (33.6\%), and has been the most reliable information (56\%).

As seen from table 3 , the majority of the youngest (29 years or less) who use Facebook $(70,7 \%)$ and Twitter (64.4\%) to get information report that political leaders' communication is in a real crisis, 
6 H. Aboulghazi.: Covid-19 Crisis Communication Management in Morocco: Investigating Male and Female Publics' Perceptions and Assessments of Moroccan Public Authorities' Crisis Response Strategies

and therefore generates social alarm and confuses the population. However, the majority of Moroccan publics who resort to all media platforms state that the government has not revealed the whole truth.

Table 3. Moroccan Publics' perceptions of the government's communication strategies based on media consumption

\begin{tabular}{|c|c|c|c|c|c|c|c|c|}
\hline Perception & $\begin{array}{l}\text { Whats- } \\
\text { App }\end{array}$ & Facebook & Twitter & $\begin{array}{l}\text { Websites/ } \\
\text { Blogs }\end{array}$ & $\begin{array}{l}\text { Printed } \\
\text { press }\end{array}$ & $\begin{array}{l}\text { Online } \\
\text { News- } \\
\text { papers }\end{array}$ & Television & Radio \\
\hline $\begin{array}{l}\text { Has always been clear } \\
\text { and sufficient }\end{array}$ & $38.8 \%$ & $23.5 \%$ & $20.6 \%$ & $30.7 \%$ & $53.2 \%$ & $22.3 \%$ & $44.6 \%$ & $33.8 \%$ \\
\hline $\begin{array}{l}\text { Has not revealed the } \\
\text { whole truth }\end{array}$ & $60.6 \%$ & $64,4 \%$ & $66.1 \%$ & $70.3 \%$ & $41.2 \%$ & $48.5 \%$ & $54.1 \%$ & $52.4 \%$ \\
\hline $\begin{array}{l}\text { Has been scheduled at } \\
\text { the appropriate time }\end{array}$ & $19.4 \%$ & $23.5 \%$ & $23.7 \%$ & $24.9 \%$ & $33.6 \%$ & $24.0 \%$ & $23.8 \%$ & $21.5 \%$ \\
\hline $\begin{array}{l}\text { Has confused the } \\
\text { Population }\end{array}$ & $48.8 \%$ & $88.5 \%$ & $77.7 \%$ & $64.1 \%$ & $45.4 \%$ & $46.7 \%$ & $45.9 \%$ & $33.4 \%$ \\
\hline $\begin{array}{l}\text { Has been the most } \\
\text { reliable information }\end{array}$ & $33.0 \%$ & $37.5 \%$ & $43.3 \%$ & $43.2 \%$ & $56 \%$ & $39.4 \%$ & $39.9 \%$ & $45.8 \%$ \\
\hline $\begin{array}{l}\text { Has generated social } \\
\text { Alarm }\end{array}$ & $43.4 \%$ & $70,7 \%$ & $68.4 \%$ & $63.2 \%$ & $51.5 \%$ & $47.9 \%$ & $48.8 \%$ & $36.6 \%$ \\
\hline
\end{tabular}

\subsection{Moroccan Publics' criticism of the management of the Moroccan government's crisis communication}

At the beginning of Covid-19 pandemic, Moroccan males and females resort to television as the main source of news and information; it has become a vital platform undertaking the task of communicating information about covid-19. In fact, this essential function has been clear in disseminating information about the effective ways that every individual should take into consideration to inhibit the spread of the virus, such as social distancing, the right ways of wearing masks, reducing contact with others, staying at home, etc.

The findings have showed that at the early stages of pandemic, $42 \%$ of the research participants stated that the most trustworthy and reliable source of information is the government. Female respondents have commented Sufficiency, congruence and consistency in health risk communication have important implications for effective health safety instruction as well as critical content interpretability and recall. 
There has been a lack of consistency and insufficient strategies of communication as far as the danger and risks of the new Coronavirus during the pandemic, which was one of the significant research findings in the present study. Respondents believe that the government truth has not been revealed by official and national media platforms (66.7\%) in the beginning of Covid-19 pandemic, it "has caused social alarm" (60.8\%), and "has confused the population" (66, 4\%). Few respondents think that political leaders disseminate "the most reliable information source" (30.6\%), and it was clear and sufficient (18\%). The most important aspect during crises is timing of communication. Besides, at the beginning of the pandemic, appropriate timing of communication is something that Moroccan male and female's users complained about, $45 \%$ of participants believe that communication has been scheduled at the appropriate times, but in the in the second fortnight, there has been a decrease in the number of respondents who believe that the government have appropriately timed communication $(33 \%)$.

However, in the first fortnight $30 \%$ of the respondents state that just half of the truth was w revealed by the government about the new virus updates; $33 \%$ that the information confused the population, and $42,6 \%$ that it has created social alarm. In addition to this, the majority of internet users and political activists on social media have criticized the Moroccan government communication management. There has been a decrease in the number of participants who think that "the information was clear and enough" (19\%), "the information was the most reliable" (15\%). At the same time however, more respondents state that political communicators and ministers have not revealed the whole truth.

An analysis by gender has revealed that there have been significant differences by both gender and age between the two fortnights of the State of Alarm. The percentage of women in the world of social media and political public sphere remains very low in Morocco, compared to that of men. With the crisis, these percentages are likely to decrease as the gender gap widens. Moroccan female participants (40\%) that the declaration of the state of emergency has forced them to stay the whole day at home doing the housework explained it, and this has just reinforced the traditional role of Moroccan women. Besides, domestic violence has increased during the lockdown.

In the first month of the lockdown, Moroccan government, particularly the spokesperson of the Ministry of health was considered a trustworthy and highly trusted source of information about Covid-19 for Moroccan female citizens (56\%). In fact, results have shown that women are more likely to trust the government and the official media than do men. Moroccan citizens did not trust media overall. However, few older male respondents (10\%) believe that the only trustworthy source of information is news media, while Moroccan young people (29 years old and under) do not show confidence in the official media (9\%) and they strongly believe that its platform does not represent them nor does it addresses their real concerns.

Table 4. Moroccan Publics' assessment of the communication strategies of the Moroccan government by fortnights

Perception $\quad$ Total $\quad \begin{gathered}\text { First } \\ \text { fortnight }\end{gathered} \begin{gathered}\text { Second } \\ \text { fortnight }\end{gathered}$


8 H. Aboulghazi.: Covid-19 Crisis Communication Management in Morocco: Investigating Male and Female Publics' Perceptions and Assessments of Moroccan Public Authorities' Crisis Response Strategies

\begin{tabular}{llll}
\hline Has always been clear and sufficient. & $18 \%$ & $25 \%$ & $19 \%$ \\
Has not revealed the whole truth & $66,7 \%$ & $30 \%$ & $70 \%$ \\
Has been scheduled at the appropriate times & $21,4 \%$ & $45 \%$ & $33 \%$ \\
Has confused the population & $66,4 \%$ & $33 \%$ & $69 \%$ \\
Has been the most reliable information & $30,6 \%$ & $49 \%$ & $15 \%$ \\
Has generated social alarm & $60.8 \%$ & $42,6 \%$ & $72 \%$ \\
\hline
\end{tabular}

\section{DISCUSSION}

The present research study examines crisis communication management in Morocco during Covid19 pandemic, which goes beyond normal political communication. In fact, long term planning and having long time to elaborate communication strategies are two important tasks that every government lacks during crisis situations. When a crisis takes place, the spokesperson of a certain government, political leaders or Prime Ministers prefer not to speak to the media or they ignore the issue, since there is often little to no time to plan elaborate and effective strategies of communication. However, they are called on to provide a quick feedback, empathic and trustworthy information to establish and maintain good rapport with the publics and win their trust. Therefore, spokespeople need immediate skills to communicate with the publics. Unfortunately, when a crisis happens, these skills cannot be suddenly built.

Therefore, public relations practitioners and communication specialists are called upon during crises for strategic crisis communication management. Public relations is a modern day profession whose main function is the management of communication between an organization and its publics (Grunig \& Hunt, 1984), In this respect, an organization could be politicians, parties or the government. Unlike normal political communication, crisis communication, which requires to be managed by public relations practitioners, is supposed to be trustworthy, transparent, honest and drawn on correct information. Besides, public relations practitioners are supposed to show empathy and understanding about the main concerns of the publics.

However, the present research findings have showed the expected decline in trust in public authorities as the health crisis evolves. There was a higher decline in trust with regard to politicians, the ministry of health, and official political spokesperson, and this general descent of trust in public authorities and sources have become obvious as time went by. A lack of conformity in messaging causes confusion among Moroccan citizens, and weakens the impact of essential crisis communication. In fact, some respondents have stated, "we don't know who to trust, and which information is important". This indicates highly deceived and confused publics during a time of a serious health crisis. Therefore, pandemic preparedness is based on trust in the information, trust in the sources, and particularly trust in public authorities.

In the current Covid-19 pandemic, communication facilitators are important to manage crisis communication to ensure that publics understand the risks of COVID-19 and follow recommendations to protect their health and limit the spread of the virus. Communication facilitators or public relations practitioners are "boundary spanners" (Tench, 2009) who listens to and brokers information between the organization and its key publics. According to Cutlip, Center, and Broom 
(2006), the goal of this role is to provide both management and publics the information they need for making decisions of mutual interest.

By managing crisis communication effectively, public relations can be a tool that helps manage or even reduce the scale and impact of a crisis. Therefore, based on research findings of the present research paper, crisis communication's main purposes are to inform publics by providing accurate and timely information about the crisis, manage public perceptions about a crisis and how politicians, parties or governments are responding to it, limit the duration or reduce the impact of the crisis by providing clear instructions on what to do or how to help, and restore confidence and provide futureoriented perspectives.

Younger people who got news from social media had negative views of authority messages and expressed more negative opinions of the government's crisis response as weeks went by. They believe that institutional political sources and mainstream news media are used to being more aligned with authorities' information at the start of a crisis. Moroccan citizens had a negative opinion about the role played by both public authorities and the official media during Covid-19 pandemic. The main complaint was related to the communication mistakes that have been made by political leaders in response to the COVID-19 pandemic, and they include, the lack of consistent and sufficient data, the lack of clarity and empathy on the part of political leaders, the delay in offering information, the slow access to the internet, unplanned and illogical decisions making which affects Moroccan publics, and which cause anger and dissatisfactions of citizens and the government's decision making. Opinions about the news media's response to the outbreak vary considerably, depending on the platform Moroccan Female and male use for obtaining news. Citizens who get the news from two network television stations and print publications are the most likely to say the news media are doing an excellent or good job responding to the coronavirus outbreak.

\section{CONCLUSIONS}

The present research paper has showed crisis communication as one of the essential competencies required to deal with a crisis situation, such as Covid-19 pandemic. In light of this health crisis, this paper examines how different forms of information and media platforms affects the way Moroccan publics' behaviors in seeking information and their perceptions of the strategies that have been use by public authorities to react to this health crisis situation during the pandemic. Findings have proved the use of different media platforms during the first four weeks of the lockdown, and showed that Moroccan male and female internet users have consumed the media excessively and sought much more information about the new virus during emergencies. Television is one of the main sources of information for Moroccans during the Corona pandemic crisis, along with other mainstream news media channels. Publics who resort to the mainstream news media for Covid-19 information express positive opinions of the government's communication strategy. Yet, the second source of information is social media. Younger male and female citizens who got news for Covid-19 information from social media had negative views of authority messages and expressed more negative opinions of the government's crisis response as weeks went by.

Using the research data, it has been found that Moroccan publics reacted positively to the dramatic events at the beginning of the crisis. As the crisis went into its acute phase, both male and female's trust in political authorities decreased significantly; and there is evidence in the data for a polarization effect according to which low-trusting citizens responded more negatively to the deepening crisis than high-trusting citizens did as the crisis evolves. 
Therefore, the present research paper is required to be conducted during this health crisis situation to assess to what extent Moroccan political public authorities are well prepared to manage an unexpected crisis situation and facing the risks of the pandemic, and therefore suggest that before a crisis happens. In fact, risk communication and preparedness are essential to public authorities to reduce serious risks and danger of a crisis. The effectiveness of crisis communication and health information across various media platforms are the main purpose of this paper, and are presented as new empirical knowledge that needs further research. Thus, explaining the use of different media platforms by different age categories and gender within a health crisis situation in Morocco, and building relationships between the selection of media platforms and criticism of crisis communication response are the main objectives of this study.

\section{REFERENCES}

[1] Austin, L., \& Yan, J., (2016). Social media and crisis communication: Explicating the social-mediated crisis communication model. In: Dudo, Anthony; Kahlor, LeeAnn (eds.). Strategic communication: New agendas. New York, NY: Routledge, pp. 163-186. ISBN: 1138184799.

[2] Bennett, W. L., \& Steven, L. (2018). The disinformation order: Disruptive communication and the decline of democratic institutions. European journal of communication, v. 33, n. 2, pp. 122-139. https://doi.org/10.1177/0267323118760317

[3] Casero-Ripollés, A. (2020). Impact of Covid-19 on the media system. Communicative and democratic consequences of news consumption during the outbreak. El profesional de la información, v. 29, n. 2, e290223. https://doi.org/10.3145/epi.2020.mar.23

[4] Coombs, W. T. (1995). Choosing the right words: The development of guidelines for the selection of the appropriate' crisis-response strategies". Management communication quarterly, 8, (4), pp. 447-476.

[5] Coombs, W. T., \& Holladay, \& Sherry J. (2009). Further explorations of post-crisis communication: Effects of media and response strategies on perceptions and intentions". Public relations review, v. $35, \mathrm{n}$. 1, pp. 1-6. https://doi.org/10.1016/j.pubrev.2008.09.011

[6] Creswell. J. W. (2009). Research Design. Qualitative, Quantitative, and Mixed Methods Approaches (3rd ed.). Thousand Oaks. CA: Sage.

[7] Cindy S.B. N., \& Jin Y. (2016). The Effectiveness of Crisis Communication Strategies on Sina Weibo in Relation to Chinese Publics' Acceptance of These Strategies, Journal of Business and Technical Communication.

[8] Cutlip, S., Center, A., \& Broom, G. (2006). Effective Public Relations (9th ed.). Upper Saddle, NJ: Pearson Prentice Hall.

[9] Edelman, E. (2020). Special report: Trust and the coronavirus. https://bit.ly/2TERtFx

[10] Figus A. (2019) Sistema Europa. L'organizzazione politica dell'Unione europea, il complesso cammino verso l'unione politica. Eurilink University Press, Rome.

[11] Fraustino, J., D.; Brooke-Fisher, L., \& Yan, J. (2017). Social media during disasters: A research synthesis and road map. In: Austin, Lucinda; Jin, Yan (eds.). Social media and crisis communication. New York, NY: Routledge, pp. 283-295. ISBN: 9781315749068

[12] Holtzhausen, D., R. \& Roberts G., F. (2009) An Investigation into the Role of Image Repair Theory in Strategic Conflict Management, Journal of Public Relations Research.

[13] Moreno, Á.; Fuentes-Lara, C. \& Navarro, C. (2020). Covid-19 communication management in Spain: Exploring the effect of information-seeking behavior and message reception in public's evaluation. $E l$ profesional de la información, 29, n. 4, e290402.

[14] Procopio, C., H. \& Procopio, S., T. (2007). Do you know what it means to miss New Orleans? Internet communication, geographic community, and social capital in crisis. Journal of applied communication research, 35(1), pp. 67-87. https://doi.org/10.1080/00909880601065722

[15] Reuter, C., \& Kaufhold, M., A. (2018). Fifteen years of social media in emergencies: a retrospective review and future directions for crisis informatics. Journal of contingencies and crisis management, (26) 1, pp. 4157. https://doi.org/10.1111/1468-5973.12196 
[16] Roslyng, M. \& Eskjær, M., F. (2017). Mediatised risk culture: News coverage of risk technologies. Health, risk \& society, v. 19, n. 3-4, pp. 112-129. https://doi.org/10.1080/13698575.2017.1286298

[17] Seeger, M.,; Sellnow, T., \& Ulmer R. (1998). Communication, organization, and crisis. Annals of the International Communication Association, 21( 1), pp. 231-276.

[18] Van-Aelst, P.; Strömbäck, J.; Aalberg, T.; Esser, F.; De-Vreese, C. H.; Matthes, J.; Hopmann, D.; Salgado, S.; Hubé, N.; Stępińska, A.; Papathanassopoulos, S.; Berganza, R.; Legnante, G.; Reinemann, C.; Sheafer, T. \& Stanyer, J. (2017). Political communication in a high-choice media environment: a challenge for democracy? Annals of the International Communication Association, 41 (1), pp. 3-27. https://doi.org/10.1080/23808985.2017.1288551

\section{AUTHOR'S BIO}

Hanane Aboulghazi is a High School Teacher of English in Morocco. She graduated with a B.A. in English studies, major 'Linguistics', from Moulay Ismail University, School of Arts and Humanities in Meknes in 2013. She obtained a Master's Degree in "Communication in Contexts" from the same university in 2015. She is currently carrying on her dissertation for the Doctor in Political Public Relations degree in Ibn Tofail University, School of Arts and Humanities. During her teaching and academic experience, she has presented research papers in various national and international conferences in the fields of public relations, political communication, cultural studies, Gender Studies, Media Studies, and Applied Linguistics. 